\title{
Third eyelid scrolling and surgical treatment - a case report
}

\author{
Mahdieh Rezaei*, Omid Azari, and Hadi Hassibi \\ Department of Clinical Science, Faculty of Veterinary Medicine, Shahid Bahonar University of Kerman, \\ Kerman, Iran
}

\section{REZAEI, M., O. AZARI, H. HASSIBI: Third eyelid scrolling and surgical treatment. Vet. arhiv 89, 591-599, 2019.}

\section{ABSTRACT}

This report describes the clinical presentation, treatment, and outcome of a dog with third eyelid scrolling associated with prolapse of the gland of the third eyelid, which was treated with a modified surgical technique, and determines whether this procedure preserves the functions of the third eyelid, reduces cartilage shortening, eliminates the recurrence and finally improves the vision. An 8-month-old male German shepherd dog was presented with ocular irritation and epiphora. Ophthalmic examination revealed an everted third eyelid associated with a prolapsed nictitans gland. We performed the Morgan pocket technique to reposition the prolapsed gland in the current case, and the incision of deformed cartilage was done simultaneously. The surgical outcome was excellent with no recurrence or other complications. The Morgan pocket technique is a suitable surgical technique, however we corrected eversion of third eyelid by cutting the central portion of the deformed cartilage rather than removing the whole or part of it. This work may provide an alternative surgical treatment of third eyelid scrolling in dog.

Key words: third eyelid; scrolling; prolapse of the gland of the third eyelid; dog

\section{Introduction}

The third eyelid, or nictitating membrane, is a triangular shaped conjunctival fold located at the medial angle of the eye. It is supported by a T-shaped hyaline cartilage (COOPER, 2010; WILLIAMS et al., 2012; ALLBAUGH and STUHR, 2013). An accessory lacrimal gland with mucous secretion is placed at the base of the nictitating membrane that produces about $30-50 \%$ of the tears (GEORGESCU et al., 2015). The outer visible edge of third eyelid is usually pigmented in dogs (COOPER, 2010). The lid protrudes over the anterior surface of the globe with passive movement, and protects the eye by partially covering its surface (BOEDEKER et al., 2010; COOPER, 2010; UKWUEZE et al., 2015).

\footnotetext{
*Corresponding author:

Mahdieh Rezaei, Department of Clinical Science, Faculty of Veterinary Medicine, Shahid Bahonar University of Kerman, Kerman, Iran, Phone: +98 9133431 675; E-mail: m.rezaei@uk.ac.ir; mahdiehrrezaei@gmail.com
} 
Rolling out of the third eyelid is termed scrolling or eversion of the nictitating membrane. It occurs due to abnormal curling of the vertical portion of the T-shaped cartilage (PEIFFER and PETERSEN-JONES, 2009; BOEDEKER et al., 2010; MAGGS et al., 2012; AMERICAN COLLEGE OF VETERINARY OPHTHALMOLOGISTS, 2016). This malformation is common in small animal practice (MAIIEL et al., 1990; BOEDEKER et al., 2010; GEORGESCU et al., 2015), and may be observed as unilateral or bilateral (MAGGS et al., 2012; ALLBAUGH and STUHR, 2013). The exact etiology of scrolling remains unknown, although it may be congenital, with some heritable mechanisms. Moreover, environmental predisposing factors, such as injuries and improper suturing, have been suggested as other underlying reasons (MAGGS et al., 2012). Most researchers believe that a difference between the growth rates of the two sides of the nictitating membrane results in scrolling (ALLBAUGH and STUHR, 2013; GEORGESCU et al., 2015). Various canine breeds can be affected, but Weimaraner, Saint Bernard, Newfoundland, Great Dane, German shorthaired pointer and Irish setter show the highest prevalence of third eyelid scrolling (RAMANI et al., 2010; MAGGS et al., 2012; ALLBAUGH and STUHR, 2013). The animals most often represented are young (COOPER, 2010).

In terms of clinical appearance, scrolled cartilage leads to a raised pink deformity at the medial canthus. Furthermore, Secondary conjunctivitis, epiphora and ocular irritation may be observed (COOPER, 2010). Some reports exist regarding the self-repair of an everted third eyelid; however, this condition should be corrected surgically for cosmetic and functional reasons (PEIFFER and PETERSEN-JONES, 2009; MAGGS et al., 2012). Various techniques have been developed for treatment of this problem, such as resection of the eyelid margin and cartilage, the temporary nictitans membrane flap, resection of the bent portion of the cartilage, cartilage resection and homograft, and finally thermal cautery. Here, we report an eversion of third eyelid associated with a prolapsed gland of the third eyelid in an eight month-old German shepherd puppy, and the correction method.

\section{Case report}

An 8-month-old, male German shepherd dog was referred to the Veterinary Teaching Hospital, Shahid Bahonar University of Kerman, Iran, with a protruding mass on the right eye associated with excessive lacrimation and photophobia. The history taken revealed that this condition had lasted for three weeks without any trauma or other ocular problems. Upon clinical examination, the protruding mass was diagnosed as a third eyelid eversion and prolapse of its gland. Also, conjunctival congestion, hyperemia and blepharospasm were observed. The Schirmer tear test of the left eye was normal, whereas in the right eye, tear production was increased to $28 \mathrm{~mm} / \mathrm{min}$. The cornea did not retain the fluorescein 
stain. Menace response, dazzle and the pupillary light reflex (both direct and indirect) were normal. Moreover, intraocular pressure measurements, using a Vintage Schiotz Tonometer, were recorded as normal. No other abnormal findings were observed during ophthalmoscopy and general clinical examinations. Scrolling associated with prolapsed gland of the third eyelid was observed in right eye, while the left eye showed only a mild form of scrolling (Fig. 1).
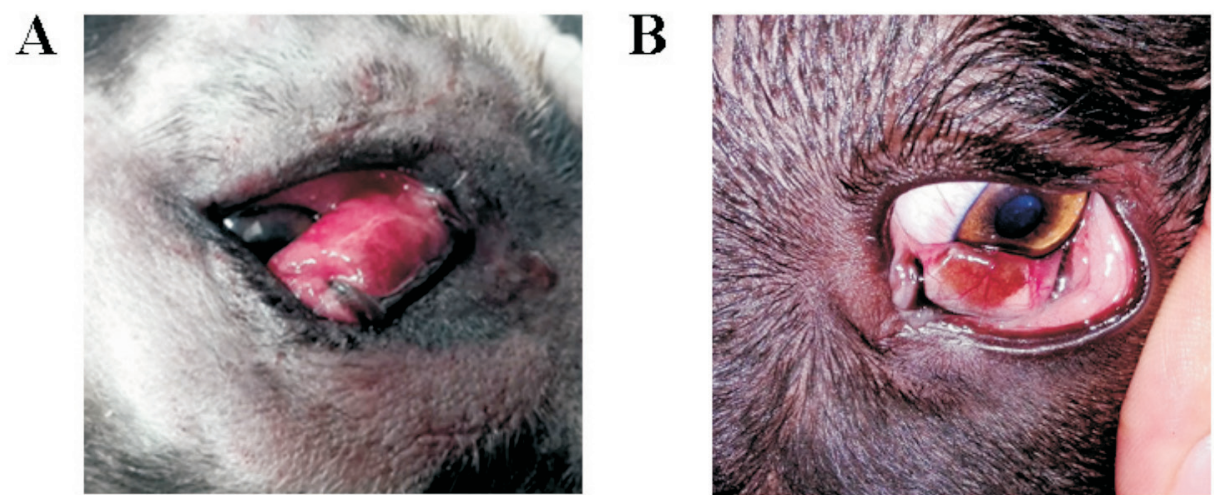

Fig. 1. Scrolling of third eyelid in an 8-month-old, male German shepherd dog. A - Right eye and B - left eye

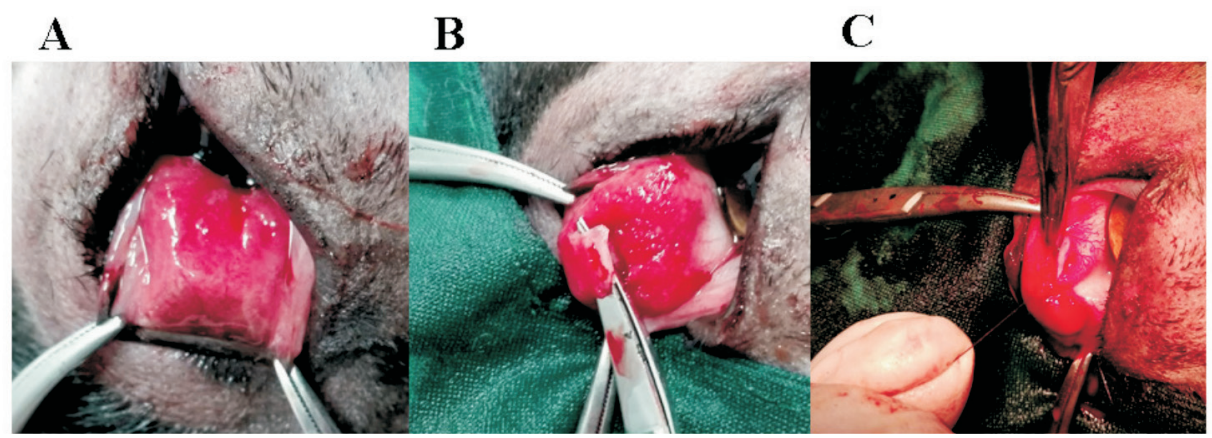

Fig. 2. Description of surgical technique A - Anchoring the nictitans membrane with forceps and extension anteriorly. B - Incision of the scrolled cartilage just below the junction of the vertical with the horizontal portion of the T. No sutures were placed. C - Repositioning of the prolapsed nictitans gland by the Morgan pocket technique, with two inverting sutures using absorbable material (6/0 Vicryl). 


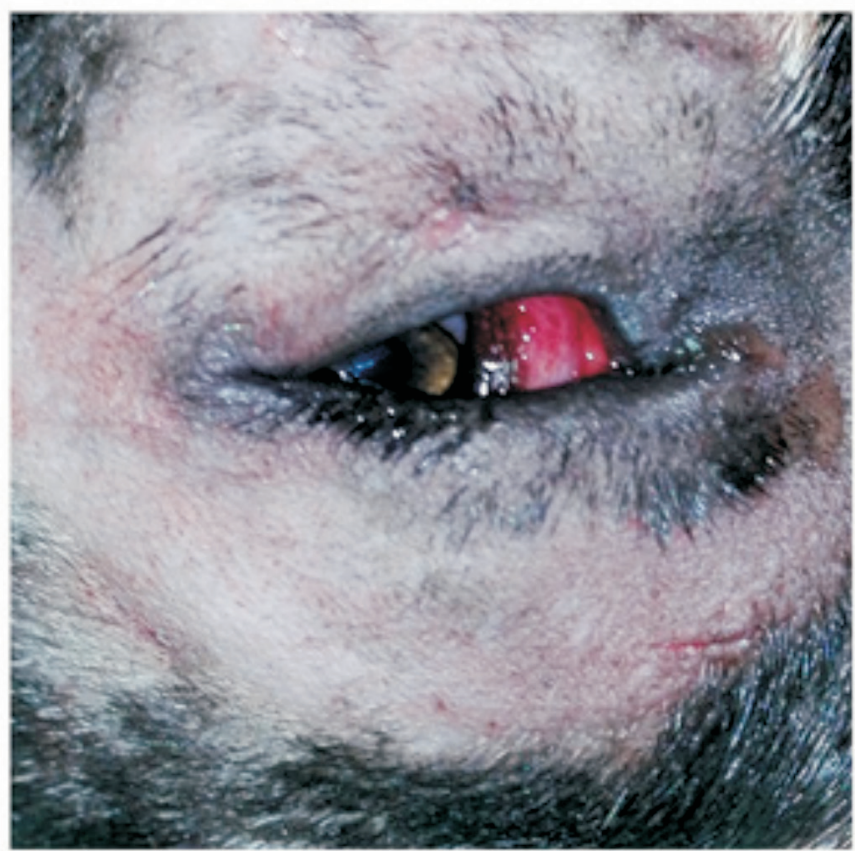

Fig. 3. Postoperative appearance of the affected eye shows normal third eyelid position following correction of the everted cartilage and repositioning of the prolapsed gland.

The prolapsed nictitans gland was also considered to be secondary to the everted lid. Treatment was initiated with $0.3 \%$ ciprofloxacin eye drops $\mathrm{q} 8 \mathrm{~h}$ and $0.5 \%$ diclofenac eye drops $\mathrm{q} 6 \mathrm{~h}$ as antibacterial and non-steroidal anti-inflammatory analgesic drugs, respectively, but this topical therapy was unsuccessful after one week. So, surgery was considered. The animal was premedicated with $0.05 \mathrm{mg} / \mathrm{kg}$ acepromazine intramuscularly. Anesthesia was induced intravenously with $10 \mathrm{mg} / \mathrm{kg}$ thiopental sodium and maintained with isoflurane. The dog was positioned in lateral recumbency, and the affected eye was surgically prepared by the standard method (MAGGS et al., 2012). The nictitans membrane was anchored with forceps and extended anteriorly. On the bulbar surface, the conjunctiva was gently dissected from the underlying cartilage by a blunt cut. The scrolled cartilage was incised with a scalpel, just below the junction of the vertical with the horizontal portion of the $\mathrm{T}$, but no sutures were placed. After that, the nictitans gland was replaced by the Morgan pocket technique, with two inverting sutures using absorbable material (6/0 Vicryl). Electrocautery was used to control the bleeding. The dog recovered uneventfully, and an Elizabethan collar was applied postoperatively to prevent self-trauma. Additionally, the patient was treated by tramadol as a strong pain 
relief agent, $0.2 \mathrm{mg} / \mathrm{kg}$ PO q12h for 3 days and ascorbic acid, $50 \mathrm{mg} / \mathrm{kg}$ PO. Ofloxacin $(15 \mathrm{mg} / \mathrm{kg}$ q12h PO for 3 days) as an antibiotic, was also prescribed due to its synergistic effect with topical ciprofloxacin. A non-steroidal anti-inflammatory drug (Flunixin meglumine $0.5 \mathrm{mg} / \mathrm{kg}$ IV once) was also injected. Additionally, ascorbic acid (50 mg/ $\mathrm{kg}, \mathrm{PO}$ ) was prescribed for improving the healing. Treatment was topically initiated with $0.3 \%$ ciprofloxacin eye drops q $8 \mathrm{~h}$ and $0.5 \%$ diclofenac eye drops q6h as antibacterial and non-steroidal anti-inflammatory analgesic drugs, respectively, and lasted for one week. Several reexaminations were done following the surgery and no other abnormal findings were observed. At the 3 month recheck, the surgical site showed complete healing and no other complications were observed.

\section{Discussion}

Third eyelid abnormalities, particularly prolapse of the gland of the third eyelid and scrolling, occur frequently in dogs. In a study conducted by ANTONIA et al. (2014), 35 out of 643 cases $(5.44 \%)$ had problems of the third eyelid and its gland, in which most them presented with prolapse of the gland of the third eyelid (ANTONIA et al., 2014). In the current case, scrolling associated with prolapse of the gland of the third eyelid was observed in the right eye, while the left eye showed only a mild form of scrolling. It seems that the prolapse of the gland of the third eyelid took place following the development of the folded cartilage.

Similar to our findings, scrolling of the third eyelid concurrent with gland prolapse was reported in a Burmese cat (KOCH, 1979). Eversion of third eyelid with prolapsed gland was reported in a study conducted by Albert (ALBERT et al., 1982). CHAHORY et al. (2004) also reported these two conditions in a Persian cat (CHAHORY et al., 2004). Differentiation of scrolling from prolapse of the gland of the third eyelid is performed by observing the cartilage convexity through the conjunctival surface (ALLBAUGH and STUHR, 2013). Due to the weakness in the junction of the vertical and horizontal portions of the T-shaped cartilage, this site is the most affected site (GELATT, 1972). The eye-related symptoms of this case, including conjunctivitis, were representative of the damage to the normal protective and clearing functions of the third eyelid. The epiphora in the present case may be attributed to impairment of optimal tear film distribution and drainage (PEIFFER and PETERSEN-JONES, 2009; ALLBAUGH and STUHR, 2013).

The goal of treatment is to improve functional performance by preserving the structural integrity (ALLBAUGH and STUHR, 2013). Despite some reports of spontaneous healing (MARTIN and LEACH, 1970), different methods, with various degrees of success, have been proposed for surgical correction of everted third eyelid. The best surgical technique is one that preserves the structural integrity and normal function of the third eyelid (ALLBAUGH and STUHR, 2013). Excision of the scrolled portion of the cartilage has 
been proposed as the most popular method (GELATT, 1972; WILLIAMS et al., 2012; ALLBAUGH and STUHR, 2013). The deformed, redundant, or buckled section of the vertical arm of the T-shaped cartilage is removed in the mentioned method (MAGGS et al., 2012). Temporary third eyelid flap placement was reported with limited success (MARTIN and LEACH, 1970). Others have recommended removal of all the cartilage, with or without the gland (JENSEN, 1971; KUHNS, 1977). MAIIE et al. (1990) proposed cartilage excision and homotransplantations to improve the function of the third eyelid. ALLBAUGH and STUHR (2013) performed thermal cautery of a canine third eyelid for treatment of cartilage eversion, which was associated with good results. These authors stated that "thermal or electrocautery is a fast, simple, and highly effective method of treatment" (ALLBAUGH and STUHR, 2013).

Removal of the scrolled portion of cartilage is performed by the bulbar or palpebral approach. Bulbar dissection is simple with less adhesion to surrounding tissue; however, there would be a lower possibility of traumatic corneal scarring using the palpebral approach (WILLIAMS et al., 2012). We carried out surgical correction of the scrolling and prolapse of the gland of the third eyelid via the bulbar approach. Excision of all or part of the cartilage has a negative effect on the stability of the third eyelid, and also results in prolapse of the gland of the third eyelid (ALLBAUGH and STUHR, 2013). Shortening of the third eyelid is a consequence of resection of the greater part of the third eyelid cartilage and removal of the central portion of the third eyelid. It is followed by loss of tension and rigidity, which is obvious histologically. Exeresis of the edges of the cartilage was unsuccessful due to inflammatory reactions following the protrusion of the sectioned cartilage's free edge into the connective tissue. Homotransplantation of the third eyelid cartilage showed complete healing 45 days post transplantation, but it is costly and time consuming. Long surgery, fine surgical instrumentation and suture material are required for cartilage resection and the homograft ( MAIIEL et al., 1990). In the study of ALLBAUGH and STUHR (2013), all the cases described were treated with cautery, and among them one Great Dane that had concurrent third eyelid gland prolapse, required subsequent gland replacement surgery (ALLBAUGH and STUHR, 2013). In the current case, the scrolled cartilage was incised with a scalpel just below the junction of the vertical and horizontal portions of the T, without any suture placement. Retaining the original shape and length and fitting into the corneal surface was achieved following this technique. MARTIN and LEACH (1970) did not detect any abnormal findings on histopathological assessment of cases with scrolling of the third eyelid; so, the scrolled part is histopathologically normal.

There are several surgical techniques to reposition the prolapsed gland. We used the pocket technique proposed by MOORE (1983) and improved by MORGAN et al. (1993), which allows the effective drainage of tears (MOORE, 1983; MORGAN et al., 1993; 
GEORGESCU et al., 2015). Since hypertrophy and instability of the gland was evident at the time of surgery, the pocket technique was used prophylactically to prevent subsequent gland protrusion. Due to the considerable importance of the nictitating membrane gland in tear production, it has been advised to save the nictitans gland instead of its removal (CHAHORY et al., 2004). Keratoconjunctivitis sicca may form following removal of the nictitating membrane gland (WILLIAMS et al., 2012). We performed the Morgan pocket technique to reposition the prolapsed gland in the current case, and the incision of the deformed cartilage was done simultaneously. The surgical outcome was excellent, with no recurrence or any other complications.

In conclusion, removal of the whole cartilage reduces rigidity of the third eyelid, so it affects its role in covering, protection and cleaning debris from the tear film (WILLIAMS et al., 2012). Moreover, removal of only the scrolled portion of cartilage results in shortening of the third eyelid, overriding of the cartilage edges and finally marginal necrosis (ALLBAUGH and STUHR, 2013). The Morgan pocket technique is a suitable surgical technique, but we modified this approach by cutting the center of the deformed cartilage, rather than removing all or part of it. This approach may possibly be suitable only for surgical treatment of the prolapse of the gland of the third eyelid performed simultaneously.

\section{References}

ALBERT, R. A., P. D. GARRETT, R. D. WHITLEY, K. L. THOMAS (1982): Surgical correction of everted third eyelid in two cats. J. Am. Vet. Med. Assoc. 180, 763-766.

ALLBAUGH, R. A., C. M. STUHR (2013): Thermal cautery of the canine third eyelid for treatment of cartilage eversion. Vet. Ophthalmol. 16, 392-395.

DOI: $10.1111 /$ vop. 12012

AMERICAN COLLEGE OF VETERINARY OPHTHALMOLOGISTS (2016): Ocular Disorders Presumed to be Inherited in Purebred Dogs. $9^{\text {th }}$ ed., The College, Baton Rouge, LA.

ANTONIA, N. A., M. K. NARAYANAN, S. ANOOP, C. B. DEVANAND, J. MARTIN, S. K. VENUGOPAL (2014): Occurrence of ophthalmic disorders in dogs. Indian. J. Vet. Res. 23, $21-24$.

BOEDEKER, N. C., T. WALSH, S. MURRAY, N. BROMBERG (2010): Medical and surgical management of severe inflammation of the nictitating membrane in a Giant Panda (Ailuropoda melanoleuca). Vet. Ophthalmol. 13 Suppl, 109-115.

DOI: $10.1111 / \mathrm{j} .1463-5224.2010 .00802 . \mathrm{x}$

CHAHORY, S., M. CRASTA, S. TRIO, B. CLERC (2004): Three cases of prolapse of the nictitans gland in cats. Vet. Ophthalmol. 7, 417-419.

DOI: $10.1111 /$ j. $1463-5224.2004 .04039 . x$

COOPER, S. (2010): The canine third eyelid. Comp. Anim. 15, 52-57.

Vet. arhiv 89 (4), 591-599, 2019 
M. Rezaei et al.: Third eyelid scrolling and surgical treatment - a case report

GELATT, K. N. (1972): Surgical correction of everted nictitating membrane in the dog. Vet. Med. Small Anim. Clin. 67, 291-292.

GEORGESCU, A. E., I. IONAȘCU, C. VLĂGIOIU (2015): Surgical reduction of everted cartilage and prolapsed third eyelid gland in a three Basset Hound family with third eyelid congenital anomalies. Sci. Works. Series C. Vet. Med. 61, 71-75.

JENSEN, H. E. (1971): Stereoscopic atlas of clinical ophthalmology of domestic animals. Mosby, Saint Louis.

KOCH, S. A. (1979): Congenital ophthalmic abnormalities in the Burmese cat. J. Am. Vet. Med. Assoc. 174, 90-91.

KUHNS, E. L. (1977): Correction of eversion of the membrana nictitans in the dog. Vet. Med. Small Anim. Clin. 72, 411-417.

MAGGS, D. J., P. E. MILLER, R. OFRI (2012): Slatter's Fundamentals of Veterinary Ophthalmology. $5^{\text {th }}$ ed., Elsevier Health Sciences, pp. 160-162.

MAIIEL, M. C., M. A. VIVESL, R. BARRERAL, J. A. BASCUAS (1990): Results and histological development of various surgical techniques for correcting eversion of the third eyelid in dogs. Histol. Histopathol. 5, 415-425.

MARTIN, C. L., R. LEACH (1970): Everted membrana nictitans in German Shorthaired Pointers. J. Am. Vet. Med. Assoc. 157, 1229-1232.

MOORE, C. P. (1983): Alternative technique for prolapsed gland of the third eyelid. In: Current Techniques in Small Animal Surgery. (Borjab, M. J., Ed), Philadelphia, pp. 52-53.

MORGAN, R. V. U. O. T., J. M. DUDDY, K. McCLURG (1993): Prolapse of the gland of the third eyelid in dogs: a retrospective study of 89 cases (1980 to 1990). J. Am. Anim. Hosp. Assoc. 29, 56-60.

PEIFFER, R. L., S. M. PETERSEN-JONES (2009): Small Animal Ophthalmology: a ProblemOrientated Approach. $4^{\text {th }}$ ed., Saunders Elsevier, Edinburgh, pp. 87-89.

RAMANI, C., S. SOORYADAS, R. DAS, R. S. KUMAR (2010): Surgical correction of everted membrana nictitans in through anterior conjunctival approach in a dog. Indian. J. Vet. Anim. Sci. 6, 104-106.

UKWUEZE, O., N. UCHECHUKWU, J. THERESAH (2015): A case of prolapsed third eyelid gland in a two month old bull mastiff. Int. J. Med. Pharm. Case. Reports. 3, 121-126.

DOI: $10.9734 /$ ijmpcr/2015/15931

WILLIAMS, D., S. MIDDLETON, A. CALDWELL (2012): Everted third eyelid cartilage in a cat: a case report and literature review. Vet. Ophthalmol. 15, 123-127.

DOI: 10.1111/j.1463-5224.2011.00945.x

Received: 29 January 2018

Accepted: 14 July 2019 


\section{REZAEI, M., O. AZARI, H. HASSIBI: Kirurško liječenje uvrnuća trećega očnog kapka - prikaz slučaja. Vet. arhiv 89, 591-599, 2019. \\ SAŽETAK}

Rad opisuje kliničku sliku, liječenje i ishod liječenja psa s izvrnućem trećega očnog kapka povezanog s prolapsom pripadajuće žlijezde. Primijenjena je modificirana kirurška tehnik kako bi se utvrdilo očuvanje funkcije trećega očnog kapka, smanjilo skraćivanje hrskavice, spriječio povratak bolesti $i$, konačno, poboljšao vid. Mužjak njemačkog ovčara u dobi od osam mjeseci imao je iritaciju oka i epiforu. Oftalmološki je pregled pokazao uvrnuće trećega očnog kapka povezano s prolapsom žlijezde za treptanje. Učinjena je tehnika Morganova džepa za repoziciju izvrnute žlijezde uz istodobnu inciziju deformirane hrskavice. Rezultat zahvata bio je izvrstan, bez povratka bolesti i drugih komplikacija. Tehnika Morganova džepa prikladna je kirurška tehnika, iako smo korigirali treći očni kapak izrezavši središnji dio deformirane hrskavice radije nego uklanjajući cijelu hrskavicu. Ovaj rad nudi alternativo kirurško liječenje uvrnuća trećega očnog kapka u psa.

Ključne riječi: treći očni kapak; uvrnuće; prolaps žlijezde trećega očnog kapka; pas 
